\title{
Kajian Penataan Tanaman Kawasan Borobudur
}

\section{Study on the Vegetation Planning for Borobudur Area}

\author{
Hari Setyawan dan Bambang Kasatriyanto \\ Balai Konservasi Borobudur \\ sivanata_raja@yahoo.com
}

\begin{abstract}
ABSTRAK
Relief cerita pada Candi Borobudur dan Candi Mendut merupakan gambaran lingkungan Jawa Kuna abad VIII-X M. Komponen lingkungan yang digambarkan pada panel relief dan menarik untuk dikaji, salah satunya adalah penggambaran tanaman pada relief. Tanaman merupakan salah satu elemen penting untuk menunjang kehidupan manusia pada masa lalu khususnya pada masa perkembangan Hindhu/ Buddha periode Jawa Tengah. Indentifikasi tanaman dapat dilakukan dengan pengamatan langsung. Setelah tanaman dapat diidentifikasi jenisnya maka konteks pengambaran tanaman berperan penting dalam menentukan kondisi lingkungan dimana tanaman tersebut tumbuh. Apabila ditarik pada masa kini, maka indentifikasi tanaman dan klasifikasi konteks penggambaran tanaman dapat bermanfaat dalam pelestarian lanskap budaya Kawasan Strategis Nasional Borobudur.
\end{abstract}

Kata Kunci: relief tanaman; jawa kuno; candi borobudur; candi mendut; tanaman; kawasan borobudur.

\begin{abstract}
The relief story of Borobudur Temple and Mendut Temple is a depiction of the Old Javanese environment of the 8th-10th century CE. The environmental components depicted in the relief panels are interesting to study, one of which is the depiction of plants in relief. Plants are one of the important elements to support human life in the past, especially during the Hindu-Buddhist period of Central Java. Plants identification can be done by direct observation. After the plants can be identified, the context of plant propagation plays an important role in determining the environmental conditions in which the plants grow. When drawn in the present, plant identification and classification of the context of the description of plants can be useful in preserving the cultural landscape of the Borobudur National Strategic Area.
\end{abstract}

Keywords: relief story; ancient java; borobudur temple; mendut temple; plants; borobudur area

\section{PENDAHULUAN}

\section{Latar Belakang}

Upaya pelestarian Candi

Borobudur dimulai sejak penemuan kembali pada tahun 1814 yang kemudian dilanjutkan dengan pemugaran oleh Pemerintah Hindia
Belanda dimulai tahun 1907. Pemugaran dengan metode dan peralatan modern dilakukan oleh Pemerintah Indonesia bekerja sama UNESCO pada tahun 1973-1983. Upaya pelestarian Candi Borobudur dalam lingkup kawasan dilakukan dengan ditetapkannya Keputusan 
Menteri Pendidikan dan Kebudayaan Nomor 286/M/2014 tentang Satuan Ruang Geografis Borobudur Sebagai Kawasan Cagar Budaya Peringkat Nasional. Adapun untuk melakukan perlindungan dan penataan ruang Kawasan Cagar Budaya Borobudur, Peraturan Presiden Nomor 58 Tahun 2014 tentang Rencana Tata Ruang Kawasan Borobudur dan Sekitarnya, ditetapkan untuk memberikan arahan dan batasan pemanfaatan ruang di Kawasan Strategis Nasional Borobudur.

Penataan ruang, pengendalian laju pertumbuhan permukiman dan infrastruktur termasuk didalamnya penataan lanskap alam dan budaya merupakan salah satu upaya untuk meningkatkan otentisitas dan integritas Candi Borobudur sebagai warisan budaya dunia. Salah satu komponen penting dari lanskap alam dan budaya Kawasan Borobudur adalah tanaman. Tanaman merupakan komponen penting pendukung situs dan kawasan cagar budaya. Penataan tanaman yang baik dan terencana akan meningkatkan kelestarian struktur maupun bangunan cagar budaya di Kawasan Borobudur, khususnya Candi Borobudur, Candi Mendut, dan Candi Pawon.

Penataan tanaman merupakan upaya untuk meningkatkan kelestarian situs dan Kawasan Cagar Budaya Borobudur. Tanaman berpotensi sebagai elemen penting yang mempunyai fungsi salah satunya adalah mengurangi fluktuasi suhu, kelembaban, dan gas berbahaya yang akan mempercepat laju pelapukan batu struktur candi. Selain itu, penataan tanaman diharapkan mampu mengurangi efek yang dapat timbul karena pencemaran udara maupun perubahan iklim pada skala mikro dan makro. Apabila dikaitkan dengan lanskap budaya Kawasan Borobudur, maka rencana penataan tanaman dapat juga dilakukan dengan pendekatan arkeologis. Data arkeologis yang dimaksud adalah gambaran lingkungan alam di Kawasan Borobudur yang dijumpai pada panel relief cerita Candi Borobudur dan Candi Mendut.

Panel relief cerita yang terpahat pada Candi Borobudur dan Candi Mendut adalah gambaran lingkungan alam dan sosial budaya Masyarakat Jawa Kuna pada saat candi tersebut dibangun dan digunakan oleh pendukung budayanya. Seperti diketahui bahwa panel relief cerita pada Candi Borobudur dan Candi Mendut adalah visualiasi dari beberapa kitab keagamaan Buddha. Dengan demikian dapat dipahami bahwa kitab yang diacu adalah dari India, namun penggambaran adegan dan setting tempat pada panel relief adalah kondisi sehari-hari di Kawasan Borobudur. Salah satu komponen lingkungan yang juga digambarkan secara jelas pada panel relief adalah tanaman. Pada tulisan ini akan disampaikan bahwa data arkeologis mengenai tanaman dapat digunakan sebagai acuan penataan tanaman di Kawasan Borobudur.

Kajian Penataan Tanaman Kawasan Borobudur merupakan kajian yang akan memformulasikan Rencana Penataan Tanaman Kawasan Borobudur sehingga dapat menjadi rujukan untuk dimanfaatkan para pengelola Kawasan Borobudur. Sebagai tahap permulaan, data relief candi merupakan data yang digunakan untuk merekonstruksi jenis tanaman pada masa lalu di 
Kawasan Borobudur. Data penggambaran tanaman pada relief cerita, baik di Candi Borobudur maupun di Candi Mendut dalam kerangka Kajian Penataan Tanaman Kawasan Borobudur merupakan salah satu petunjuk data acuan. Namun demikian, data acuan tersebut harus dideskripsikan dan diindentifikasi konteks penggambaran tanaman tersebut secara lebih mendalam. Deskripsi juga dapat diperdalam dengan analisa dari data prasasti Jawa Kuna maupun naskah kesusastraan yang sezaman dengan pembangunan dan penggunaan Candi Borobudur.

Tahap selanjutnya, setelah jenis tanaman dan konteks penggambarannya dapat diidentifikasi maka klasifikasi dan analisis kontekstual dilakukan untuk menegaskan komponen lingkungan yang terkait didalamnya. Salah satu komponen lingkungan yang terkait dengan tanaman adalah gambaran lahan/tempat tanaman tersebut tumbuh ataupun dibudidayakan. Gambaran lahan atau lanskap tempat tanaman tumbuh, akan menentukan fungsi penanaman suatu jenis tanaman. Setelah semua tanaman dapat ditentukan lanskap maupun habitatnya maka selanjutnya adalah melakukan rekonstruksi kondisi lingkungan Kawasan Borobudur pada abad VIII-X M.

Pada tahap klasifikasi dan analisa kontekstual data interpretasi prasasti Jawa Kuna dapat digunakan untuk menjelaskan indikasi tempat tumbuh tanaman beserta maknanya. Data prasasti juga dapat digunakan sebagai pelengkap dalam interpretasi jenis tanaman yang tumbuh dan dimanfaatkan pada masa Jawa Kuna. Selain itu, naskah Ramayana Jawa
Kuna yang sezaman juga merupakan data yang dapat digunakan untuk analisa kontekstual dari tanaman pada masa Jawa Kuna.

Tahap akhir Kajian Penataan Tanaman Kawasan Borobudur akan berupa rekomendasi rencana penataan tanaman dan landscaping di Kawasan Borobudur. Hal ini penting karena untuk menentukan lokasi ditanamnya suatu jenis tanaman khususnya pada lingkungan situs, harus diketahui dan diperhatikan dampaknya. Tanaman yang di tanam di lingkungan situs harus mempunyai karakteristik yang menunjang pelestarian struktur candi dan lingkungannya. Untuk itu, perlu dipilah-pilah kembali jenis tanaman yang telah diidentifikasi pada tahap sebelumnya.

\section{TINJAUAN PUSTAKA}

\section{Penelitian Terdahulu}

Terkait dengan identifikasi flora pada masa Jawa Kuna, berikut ini adalah beberapa penelitian yang salah satu tujuan adalah melakukan identifikasi tanaman pada relief candi. Adapun relief candi yang digunakan sebagai sumber data primer adalah pada Candi Borobudur, Candi Prambanan, Candi Sojiwan, dan Candi Mendut. Candi-candi tersebut merupakan candi yang dibangun di era Kerajaan Mataram Kuna Periode Jawa Tengah abad VIII-X M. Selain merupakan candi kerajaan yang megah, candi tersebut tentunya memiliki penggambaran relief yang naturalis, sehingga dapat dilakukan identifikasi dan interpretasi pada setiap panelnya.

Kajian terkait identifikasi tanaman pada tahun 2000 dengan 
judul "Eksistensi dan Eksploitasi Sumberdaya Lingkungan Jawa Kuna, Kajian Relief Candi Borobudur, Mendut, dan Sojiwan" dilakukan oleh Tim Balai Arkeologi Yogyakarta. Selain itu, walaupun tidak mengidentifikasi semua penggambaran tanaman pada Candi Borobudur, pada tahun 2005 dan 2006 Balai Konservasi Borobudur telah melakukan terkait dengan potensi flora. Adapun kajian pada tahun 2005 berjudul "Jenis dan Bentuk Pengobatan Pada Relief Candi Borobudur" sedangkan di tahun 2006 berjudul "Penataan Tanaman Pada Zona I Untuk Mendukung Kelestarian Candi Borobudur". Kajian yang lebih mendetail terkait identifikasi, analisis, dan interprestasi tanaman pada Candi Prambanan dan Candi Sojiwan diselesaikan oleh penulis pada tahun 2007 dengan judul "Potensi dan Pengelolaan Sumberdaya Alam Flora Pada Masyarakat Jawa Kuna Abad IX-X M, Studi Kasus Relief Candi Prambanan dan Candi Sojiwan”. Secara singkat dapat disampaikan bahwa kajian tersebut di atas merupakan kajian yang dimulai dari indentifikasi relief tanaman yang kemudian diinterpretasi untuk merekonstruksi lingkungan Jawa Kuna khususnya menyangkut tanaman maupun budidaya tanaman.

Khusus mengenai studi
tanaman pada relief Candi Borobudur telah diulas secara umum oleh Cammerloher dan van de Brink dalam jurnal De Tropische Natuur bulan Agustus dan Oktober 1931. Cammerloher dalam artikel berjudul "Wat de Boroboedoer Den Natuuronderzoeker Leert" mengulas tentang jenis-jenis pohon yang digambarkan pada relief cerita Candi
Borobudur. Sementara, van de Brink dalam artikel berjudul "Welte Planten Vindt Men op de Boroboedoer Afgebeeld" mengulas mengenai tanaman yang dikelola oleh manusia masa lalu dari relief Candi Borobudur. Adapun ulasan mendetail mengenai jenisjenis/spesies tanaman yang digambarkan pada relief Candi Borobudur ditulis oleh Steinman pada tahun 1934, dengan judul "De op de Boroboedoer Afgebeelde Plantenwereld". Tulisan tersebut dimulai dari pengamatan mengenai relief cerita pada Candi Borobudur dan Prambanan yang kemudian mendeskripsikan tanaman sesuai dengan kenampakannya untuk kemudian dikelompokkan berdasarkan spesiesnya.

\section{Data Kesejarahan dan Lingkungan Jawa Kuna Abad IX-X M}

Kerajaan Mataram Kuna periode Jawa Tengah berbasis pada sektor pertanian. Hal ini dibuktikan dengan banyaknya prasasti yang berkaitan dengan penetapan sima berupa sawah. Indikasi ini kemudian diperkuat dengan perpindahan pusat pemerintahan dari Mdaň ri Poh Pitu (Kedu-saat ini) ke Mdaň ri Mamrati (Prambanan-saat ini) karena tanahnya yang subur dan cocok untuk persawahan dan terletak di sekitar gunungapi, sehingga tanahnya mengandung unsur hara yang sangat diperlukan khususnya bagi tanaman padi (Darmosoetopo, 2003: 37). Jabatan seperti hulu air, pejabat yang mengatur dan bertanggungjawab terhadap tata air pada lahan pertanian (van Der Meer, 1979: 63, dalam Darmosoetopo, 2003: 57) dijumpai 
dalam sejumlah prasasti, antara lain Prasasti Jurungan (876 M), membuktikan bahwa pertanian sawah memegang peranan penting di Kerajaan Mataram Kuna periode Jawa Tengah.

Karajaan Mataram Kuna periode Jawa Tengah agaknya menitikberatkan pada sektor pertanian. Hal ini dibuktikan dengan banyaknya prasasti yang berkaitan dengan penetapan sima berupa sawah. Indikasi ini kemudian diperkuat dengan perpindahan pusat pemerintahan dari Mdaň ri Poh Pitu (Kedu-saat ini) ke Mdaň ri Mamrati (Prambanan-saat ini) karena tanahnya yang subur dan cocok untuk persawahan dan terletak disekitar gunungapi, sehingga tanahnya mengandung unsur hara yang sangat diperlukan khususnya bagi tanaman padi (Darmosoetopo, 2003: 37). Selain pada sektor pertanian Kerajaan Mataram Kuna periode Jawa Tengah juga mengandalkan penghidupannnya pada sektor perdagangan. Beberapa jenis barang dagangan yang disebut dalam prasasti adalah ternak (kambing, lembu, kerbau, itik), hasil pertanian (beras, garam), dan hasil kerajinan (hasil pandai besi). Di antara barang dagangan yang disebut adalah pakaian atau alat-alat dari tembaga, kapas, wungkudu atau mengkudu, lga atau minyak, gula, wras atau beras, lawe, mayang atau pinang, dan bawang (Darmosoetopo, 2003: 60-61).

Kawasan Borobudur pada abad IX-X M diasumsikan sebagai salah satu pusat kerajaan Mataram Kuna periode Jawa Tengah. Wilayah kerajaannya yang luas meliputi, seluruh Daerah Istimewa Yogyakarta dan sebagian Jawa Tengah saat ini.
Kawasan Prambanan memiliki beberapa bentukan lahan, yaitu bentukan asal gunungapi, bentukan asal struktural, bentukan denudasional, bentukan asal fluvial, bentukan asal marin, dan bentukan asal angin atau eolin (Mundardjito, 2002: 95-96). Menurut Mundardjito (2002: 95) bentuklahan seperti yang disebut di atas tidak hanya didasarkan pada satu faktor geomorfologi saja, melainkan juga mempertimbangkan sejumlah faktor geomorfologi secara keseluruhan dan bersama-sama. Faktor-faktor yang dimaksud adalah konfigurasi permukaan bumi atau topografik (morfografi), ukuran kuantitatif (morfometri); morfoproses yang mengakibatkan perubahan bentuk lahan; morfostruktur pasif; unsur tenaga endogen (morfostruktur aktif); tenaga eksogen (morfodinamika); morfokronologi; dan morfoaransemen.

\section{Relief Cerita Candi Borobudur}

Candi Borobudur adalah bangunan suci bercorak keagamaan Buddha, sehingga tidak diragukan lagi bila Candi Borobudur merupakan suatu mandala yang direpresentasikan berupa tingkatan sebagai sarana bermeditasi. Relief cerita yang dipahatkan pada dinding dan pagar langkan Candi Borobudur tak ubahnya seperti kitab suci keagamaan yang digambarkan dalam bentuk objek lingkungan kehidupan manusia pada masa Jawa Kuna abad IX-X. Cara untuk membaca cerita relief yang dipahatkan pada dinding maupun pagar langkan Candi Borobudur adalah dimulai dan diakhiri pada pintu gerbang sisi timur pada setiap tingkatannya. Hal ini dapat diartikan bahwa candi menghadap ke timur meskipun pada 
keempat sisinya sama. Relief simbolis maupun relief cerita pada Candi Borobudur dijumpai pada bagian kamadhatu dan rupadhatu

Panel relief cerita Candi Borobudur, kesemuanya berbentuk persegi panjang dengan ukuran yang bervariasi. Panel relief yang berada pada posisi paling bawah, yaitu tingkat kamadhatu pada kaki candi adalah relief Karmawibhangga. Relief Karmawibhangga saat ini dapat dilihat hanya pada sisi tenggara candi karena sengaja dibuka. Hal ini dikarenakan relief ini berada pada kaki candi yang tertutup oleh struktur selasar dan undag candi. lorong I, baris atas. Relief Jataka/Avadana menghiasi bagian dinding baris bawah dan pagar langkan lorong I baris bawah dan atas. Pada lorong diatasnya yaitu lorong II, pada pagar langkan masih dipahatkan relief cerita Jataka/Avadana, tetapi pada bagian dindingnya dipahatkan relief Gandavyuha sampai dengan lorong IV. Pada lorong yang terakhir dari tingkat Rupadhatu, yaitu pada lorong IV dihiasi oleh relief Gandavyuha, baik pada dinding maupun pada pagar langkan. Posisi, jumlah, ukuran, dan tema cerita relief pada Candi Borobudur dapat dilihat di Tabel 1.

Tabel 1. Posisi, jumlah, ukuran, dan tema cerita relief pada Candi Borobudur.

\begin{tabular}{|c|c|c|c|c|c|}
\hline \multirow{2}{*}{ Tingkat } & \multirow{2}{*}{ Posisi } & \multicolumn{2}{|c|}{ Ukuran Panel (m) } & \multirow{2}{*}{ Cerita Relief } & \multirow{2}{*}{$\begin{array}{l}\text { Jumlah } \\
\text { Panel }\end{array}$} \\
\hline & & panjang & tinggi & & \\
\hline Kaki candi & $\begin{array}{l}\text { Kaki candi yang tertutup selasar } \\
\text { dan undag }\end{array}$ & 2,10 & 0,87 & Karmawibhangga & 160 \\
\hline \multirow{4}{*}{ Lorong I } & Dinding lorong $\mathrm{I}$, baris atas & $1,91-2,84$ & 0,80 & a. Latitavistara & 120 \\
\hline & Dinding lorong I, baris bawah & $1,91-2,84$ & 0,80 & b. jataka/avadana & 120 \\
\hline & $\begin{array}{l}\text { Pagar langkan I, sisi dalam, baris } \\
\text { atas }\end{array}$ & $0,84-2,56$ & 0,63 & a. jataka/avadana & 372 \\
\hline & $\begin{array}{l}\text { Pagar langkan I, sisi dalam, baris } \\
\text { bawah }\end{array}$ & $0,84-2,55$ & 0,60 & b. jataka/avadana & 128 \\
\hline \multirow[b]{2}{*}{ Lorong II } & Dinding lorong II & $1,73-2,27$ & 1,22 & Gandavyuha & 128 \\
\hline & $\begin{array}{l}\text { Pagar langkan lorong II, sisi } \\
\text { dalam }\end{array}$ & $0,50-2,04$ & 0,60 & jataka/avadana & 100 \\
\hline \multirow[b]{2}{*}{ Lorong III } & Dinding lorong III & $1,31-3,47$ & 1,10 & Gandavyuha & 88 \\
\hline & $\begin{array}{l}\text { Pagar langkan lorong III, sisi } \\
\text { dalam }\end{array}$ & $1,04-2,07$ & 0,64 & Gandavyuha & 88 \\
\hline \multirow[b]{2}{*}{ Lorong IV } & Dinding lorong IV & $1,26-2,72$ & 1,05 & Gandavyuha & 72 \\
\hline & $\begin{array}{l}\text { Pagar langkan lorong IV, sisi } \\
\text { dalam }\end{array}$ & $0,87-2,08$ & 0,61 & Gandavyuha & 84 \\
\hline \multirow[t]{3}{*}{ Jumlah } & & & & & 1460 \\
\hline & Tingkat kamadhatu & & & & \\
\hline & Tingkat rupadhatu & & & & \\
\hline
\end{tabular}

Relief cerita pada tingkatan diatasnya adalah relief Lalitavistara dan Jataka/Avadana. Relief ini menghiasi lorong I, yaitu pada sisi dinding dan pagar langkan. Khusus untuk relief cerita lalitavistara, relief ini hanya dipahatkan pada dinding
Menurut Bhikhu Aryamaitri dalam Kendahjaya (1995: xi), Candi Borobudur merupakan mahakarya sempurna, baik dilihat dari segi estetika maupun keagamaan yang menyampaikan ajaran Sang Buddha, yaitu Karmawibhangga, Lalitavistara 
yang merupakan ajaran pelepasan samsara (hinayana), Jatakamala, Avadana, Gandavyuha, dan Bhadracari yang merupakan ajaran Bhodisatwa (mahayana), serta ajaran Vajrayana yang menjelaskan garbhadhatu mandala dan bhagavat, seperti yang terdapat di dalam Sarvatathagata-Tattvasamgraha dan

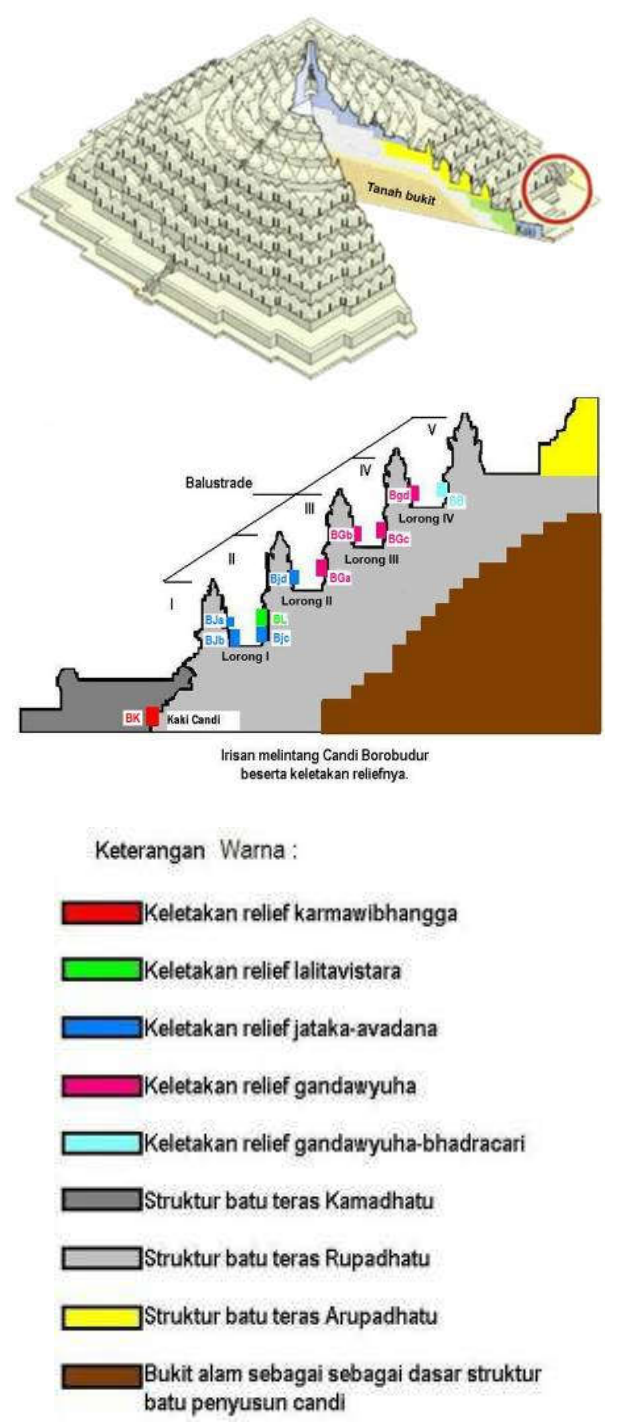

Gambar 1.Keletakan relief cerita pada dinding dan pagar langkan Candi Borobudur (dok: penulis,2007). Ilustrasi irisan Candi Borobudur pada gambar paling atas, dimodifikasi penulis dari http://id.wikipedia.org/wiki/Borobudur.
Vajrasekhara-Tantra.

\section{METODE}

\section{Indentifikasi Tanaman}

Relief merupakan ungkapan nyata yang dapat dilihat dari ide yang ada didalam diri seniman pembuatnya, dengan kata lain bahwa seniman (shilpin) yang akan memvisualisasikan sebuah naskah cerita dalam bentuk relief akan berpatokan kepada lingkungan alam dan manusia disekitarnya untuk mentransfer sebuah naskah cerita ke suatu bentuk seni. Dalam hal ini, ide tersebut berupa berbagai cerita yang oleh para seniman Jawa abad IXXVI diwujudkan dalam bentuk konkret. Karena dimaksudkan sebagai penggambaran cerita, maka didalam relief terdapat susunan bentuk-bentuk tertentu oleh si seniman sedapat mungkin diusahakan mencerminkan keadaan dan peristiwa yang terjadi didalam cerita bersangkutan. Oleh karena itu didalam relief, munculnya sosok tubuh tokoh-tokoh yang disebut dalam cerita beserta bentuk-bentuk tertentu (rumah, pohon, sungai, dsb) sebagai petunjuk tentang situasi dan kondisi tempat terjadinya sebuah peristiwa adalah yang diharapkan (Kusen, 1984).

Berdasarkan penjelasan di atas, dapat disampaikan bahwa relief sebenarnya merupakan gambaran dari lingkungan masa lalu yang diceritakan kembali melalui bentuk pahatan yang berdasarkan sebuah karya sastra. Maka dari itu, relief tanaman yang digunakan dalam penelitian ini adalah data dari relief Candi Borobudur dan Candi Mendut. Hal ini karena pada kedua 
candi tersebut dijumpai relief cerita yang diambil dari naskah kesusastraan masa lalu. Adapun pengambilan data relief tanaman didasarkan pada berbagai persyaratan yang seperti tersebut di bawah ini:

1. Relief yang digunakan sebagai data adalah relief cerita pada Candi Borobudur dan relief Candi Mendut.

2. Merupakan relief tanaman yang bergaya naturalis, bukan simbolis seperti hiasan sulur-suluran, kalpataru, purnakalasa, maupun floral geometrical.

3. Merupakan bagian dari relief cerita yang diambil dari naskah kesusastraan, karena relief cerita merupakan relief yang menggambarkan sebuah aktifitas, perjalanan, proses, maupun suatu aktivitas dari satu atau beberapa orang tokoh baik manusia atau hewan. Diharapkan gambaran pada relief adalah gambaran yang sesungguhnya dari suatu jenis tanaman beserta konteks penggambarannnya.

4. Menggambarkan bagian-bagian terpenting dari tanaman yang bersangkutan misalnya buah, batang, daun, maupun tulang daun atau bagian lain yang dapat menjadi petunjuk untuk mengidentifikasikan jenis tanaman dan konteks penggambarannya.

Dalam melakukan identifikasi jenis tanaman dilakukan secara morfologis penggambarannya pada relief. Menurut van Steenis (2003: 12) setiap tanaman mempunyai sifat karakteristik umum yang membentuk kelompok dari divisio hingga ke tingkat yang paling rendah yaitu, subspesies.
Cara yang dilakukan hanyalah menggunakan ciri fisik yang dominan yang dapat menjadi penanda jenisnya, misalnya daun, batang, buah, maupun akar. Meskipun cara ini kurang akurat, tetapi merupakan cara yang dapat dilakukan untuk mengidentifikasikan jenis tanaman pada relief.

Walaupun relief yang diambil sebagai data adalah relief naturalis, tetapi tanaman yang digambarkan dalam relief, belum tentu sesuai dengan keadaan sesungguhnya, terutama dari segi morfologi dan morfometri. Sebagian besar relief tanaman pada candi lebih menonjolkan anatomi daun, batang, dan buah dengan ukuran yang tidak diperhatikan. Sebagai contoh dapat diamati pada relief (lihat Gambar 2), bahwa penggambaran pohon kelapa, mangga, dan durian digambarkan dengan tinggi yang sama dan ukuran lebih rendah dari keadaan aslinya (tanpa mempertimbangkan skala).

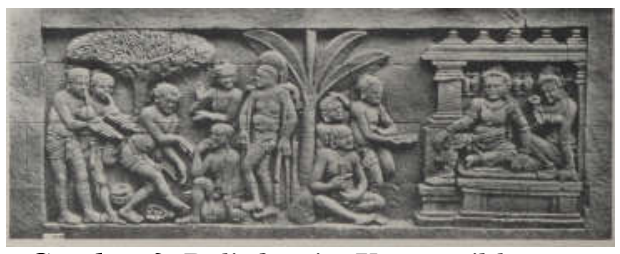

Gambar 2. Relief cerita Karmawibhangga Candi Borobudur, no.39 (Sumber: Rep: van Erp)

Untuk identifikasi jenis tanaman dilakukan secara langsung berdasarkan penanda fisik yang dijumpai pada penggambaran tanaman. Setelah itu, baru disesuaikan dengan referensi terkait jenis tanaman pada tingkat spesies/genus/famili. Berikut ini adalah salah satu contoh identifikasi tanaman pada relief Karmawibhangga pada kaki Candi Borobudur. 
Relief Karmawibhangga nomor. 39 merupakan bagian dari cerita Karmawibhangga. Relief tersebut menggambarkan pertunjukan musik yang dibawakan oleh sekelompok pemusik keliling untuk menghibur bangsawan yang duduk di atas singgasana bersama istrinya. Pertunjukan musik tersebut tampaknya juga disaksikan oleh warga setempat. Beberapa warga desa yang menyaksikan tampak bergembira dengan menari dan bertepuk tangan. Alat musik yang tampak diantaranya organ mulut dan sebuah kotak persegi panjang, bergerigi yang dibunyikan dengan pemukul berbentuk tongkat kecil (Krom, 1927).

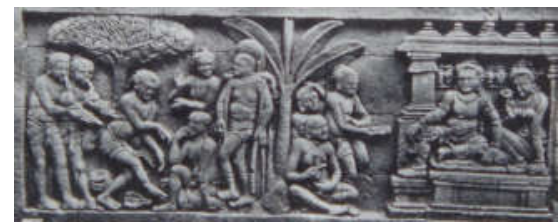

Gambar 3. Relief cerita Karmawibhangga seri O no. 39 pada kaki Candi Borobudur kuadran terdapat gambaran relief pohon bodi (Ficus reliegiosus) dan relief pohon pisang (Musa paradisiaca). (Sumber: Rep: van Erp)

\section{Relief tanaman yang} digambarkan pada relief 39.1 merupakan tanaman dalam bentuk pohon, salah satunya adalah pohon yang besar dan rindang (gambar 3). Pada foto 39.1 merupakan pohon dengan batang yang lurus dan bercabang. Daunnya lebat, bertangkai, dengan bentuk menyerupai jantung dan tulang daun yang diganbarkan dengan tegas membagi daun secara membujur menjadi dua bagian. Pada foto 39.2 merupakan pohon dengan batang yang lurus dan tidak bercabang. Daunnya jarang, berbentuk kipas tulang daunnya digambarkan dengan tegas membagi daun secara membujur menjadi dua bagian. Salah satu daunnya diagambarkan menggulung dengan posisi tegak diatas batang. Pada kedua jenis pohon tersebut tidak dijumpai buah.

Pohon dengan ciri-ciri seperti pada foto 39.1 adalah pohon bodi (Ficus religiosus) sedangkan pada foto BK 39.2 adalah pisang (Musa paradisiaca)

\section{Identifikasi Konteks Penggambaran} Analisis kontekstual dimaksudkan untuk menghubungkan keterkaitan antara relief dengan artefak lainnya yang ditemukan dalam matrik atau konteks tempat relief dipahatkan. Sehingga didalam analisis kontekstual ini maka posisi relief pada bidang sangat penting karena akan menjawab fungsi penempatan relief tersebut (Puslitbang Arkenas, 2008: 108).

Pengambaran tanaman pada relief apabila dilakukan analisis kontekstual maka akan diketahui kondisi disekitarnya. Dengan demikian juga akan dapat diidentifikasi pada lahan apa ataupun pada lingkungan apa tanaman tersebut dijumpai ataupun ditanam.

Salah satu contoh identifikasi konteks penggambaran tanaman pada suatu bentuk lahan dapat dilihat pada relief Karmawbhangga seri O no. 123. Relief tersebut menggambarkan beberapa tanaman yang berada di sekitar permukiman dan dibatasi oleh pagar. Dengan demikian dapat diidentifikasi bahwa lahan yang yang ditumbuhi beberapa tanaman dan dibatasi dengan pagar merupakan kebun yang dikelola oleh masyarakat pedesaan saat itu. Kebun adalah salah satu jenis lahan yang diusahakan oleh masyarakat Jawa Kuna, dalam prasasti disebut kbuan, kabunan, atau kubvan. 
Terdapat dua asumsi mengenai definisi kebun pada masa Jawa kuna. Pertama adalah lahan untuk menanam palawija, tanaman buah, herba, maupun tanaman rempahrempah yang berada dekat dengan tempat tinggal. yang kedua adalah kebun atau perkebunan, yaitu lahan luas yang dikelola secara besarbesaran untuk mendapatkan keuntungan dengan menanam tanaman komersial sebagai komoditas perdagangan. Definisi yang kedua dari kebun memberikan pengertian bahwa kebun adalah lahan yang ditanami berbagai tipe tanaman campuran, seperti tanaman tahunan (annual plant) dan tanaman ramuan masak atau jamu di samping tanaman keras berumur panjang (perennial plant). Terkadang kebun lebih diusahakan untuk satu jenis tanaman perdagangan tertentu, seperti pala, lada, cengkeh, kopi, karet, tebu, dll (Kartodirdjo dan Suryo, 1991: 15). Definisi yang kedua juga dapat diidentikkan dengan istilah kbonageng seperti yang disebut dalam Prasasti Kuti $(840$ M), yang artinya kebun besar atau kebun kerajaan (Sarkar, 1971: 84).

Relief seri O, no. 123 (lihat Gambar 4) memberikan gambaran kebun yang merupakan lahan yang dekat dengan tempat tinggal. Beberapa tanaman yang ditanam di kebun adalah pisang (Musa paradisiaca L), gelagah (Saccharum spotaneum $L$ ), pohon mangga (Mangifera sp), dan pohon pinang sirih (Areca catechu L). Salah satu jenis kebun yang diusahakan oleh masyarakat Jawa Kuna yang disebut dalam Prasasti Watukura A (902 M) adalah těbuan atau kebun tebu (Sarkar,1972).

\section{PENGGAMBARAN TANAMAN PADA RELIEF CANDI}

\section{Candi Mendut}

Candi Mendut berada pada lokasi administratif di Desa Mendut, Kecamatan Mungkid, Kabupaten Magelang Jawa Tengah. Candi

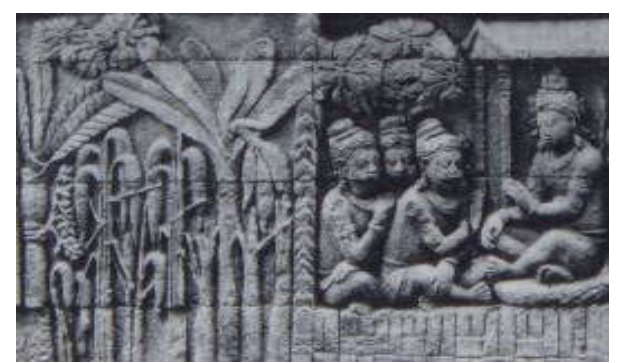

Gambar 4.Relief kebun pada Relief Cerita Karmawibhangga seri O, no. 123, pada kaki Candi Borobudur. (Sumber: Rep: van Erp)

Mendut berada tiga kilometer sebelah timur Candi Borobudur. Hingga tahun 1836 candi ini masih dalam kondisi runtuh dan tertutup oleh akar dan semak-semak. Candi ini menghadap ke Barat dengan bentuk arsitektur klasik tua dan mempunyai sebuah bilik utama yang besar dengan tiga buah arca Buddha dengan tinggi lebih dari dua meter.

Candi Mendut adalah candi dengan corak keagamaan Buddha Mahayana yang didirikan sekitar abad VIII M, oleh dinasti Sailendra atau semasa dengan Candi Borobudur (Kempers, 1959: 37). Susunan Candi Mendut terdiri kaki, tubuh, dan atap. Kaki candi dihiasi dengan ornamenornamen yang dipahatkan pada panel-panel yang berjumlah 31 buah. Pada bilik utama Candi Mendut, dijumpai tiga buah arca Buddha. Arca yang menghadap ke barat adalah Sakyamuni dengan posisi duduk dengan sikap tangan dharmacakramudra. Arca Sakyamuni melambangkan perjalanan Buddha 
dalam mengajarkan ajaran duniawi di taman rusa Benares. Hal ini terlihat pada relief dua ekor rusa dengan sebuah roda dharma diantara dua rusa tersebut yang berada dibawah kaki arca Sakyamuni. Dua arca lainya adalah Bodhisattva Awalokiteswara dan Bodhisattva Vajrapani. Awalokiteswara menghadap ke selatan dengan sikap tangan varamudra sedangkan Vajrapani menghadap ke Utara dengan sikap tangan simhakarnamudra (Moertjipto dan Prasetyo, 1993: 79-83).

Relief yang menarik dari Candi Mendut adalah relief cerita Jataka yang menghiasi tubuh candi bagian bawah dekat dengan selasar. Releif cerita tersebut diantaranya adalah relief Sumsumara Jataka. Sumsumara Jataka merupakan salah satu tema jataka yang menceritakan mengenai Bodhisattva yang menjelma dalam bentuk binatang yang memberi pelajaran kepada manusia.

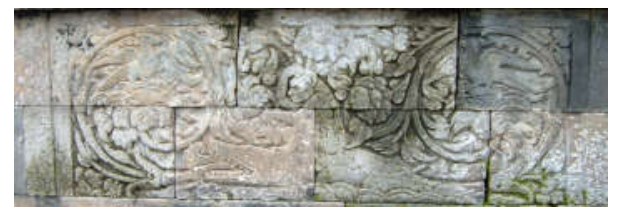

Gambar 5. Relief cerita Sumsumara Jataka pada Candi Mendut (Sumber: Penulis)

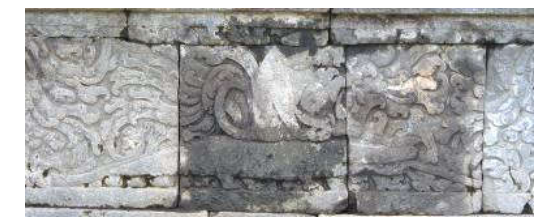

Gambar 6. Relief cerita Sumsumara Jataka pada Candi Sojiwan (Sumber: Penulis)
Gambar 5 adalah relief Jataka pada Candi Mendut. Relief tersebut ternyata mempunyai kesamaan dengan relief pada Candi Sojiwan (Gambar 6) dari segi cerita maupun penggambarannya. Perlu diketahui bahwa Candi Sojiwan juga merupakan Candi Buddha yang akan digunakan sebagai sampel dalam penelitian ini.

Candi Mendut mempunyai penggambaran relief naturalis dengan tema cerita binatang atau Tantri maupun Jataka (Kempers, 1959: 62). Relief cerita binatang adalah cerita yang digambarkan dalam relief dengan karakter binatang sebagai tokoh utamanya. Binatang dalam cerita ini bertingkah laku, berbuat, dan bertindak sebagaimana manusia dalam masyarakat. Hal yang diceritakan adalah mengenai kehidupan sehari-hari dalam masyarakat sehingga apabila binatang dalam sebuah relief pada Candi Mendut diamati maka seakan-akan karakter binatang dalam relief tersebut adalah tindakan atau perbuatan manusia dalam bermasyarakat (Leach, 1949: 361). Bentuk-bentuk seperti binatang, manusia, maupun tumbuh-tumbuhan yang digambarkan dalam relief Candi Mendut sebagian besar merupakan penggambaran yang nyata atau tepat seperti gambaran pada alam sekitarnya (Sudarsono dalam Dipodjodjo, 1983: 17). 
Relief pada Candi Mendut mendominasi bagian kaki hingga atap candi, artinya hampir semua bagian

Tabel 2. Jenis tanaman dan konteks penggambarannya pada relief cerita Candi Mendut.

\begin{tabular}{|c|c|c|}
\hline No. & Jenis Tanaman & $\begin{array}{l}\text { Konteks } \\
\text { Tanaman }\end{array}$ \\
\hline 1 & $\begin{array}{l}\text { Mangga (mangifera } \\
\text { sp) }\end{array}$ & permukiman \\
\hline 2 & $\begin{array}{l}\text { Mangga (mangifera } \\
\text { sp) }\end{array}$ & hutan \\
\hline 3 & $\begin{array}{l}\text { Jambu dersana } \\
\text { (Eugenia } \\
\text { malaccensis } L)\end{array}$ & pertapaan \\
\hline 4 & $\begin{array}{l}\text { Mangga (Mangifera } \\
\text { sp) }\end{array}$ & permukiman \\
\hline 5 & $\begin{array}{l}\text { Mangga (mangifera } \\
\text { sp) }\end{array}$ & permukiman \\
\hline 6 & $\begin{array}{l}\text { ketapang } \\
\text { (Terminalia catappa } \\
\text { L) }\end{array}$ & hutan \\
\hline 7 & $\begin{array}{l}\text { Jambu dersana } \\
\text { (Eugenia } \\
\text { malaccensis } L \text { ) }\end{array}$ & pertapaan \\
\hline 8 & $\begin{array}{l}\text { pisang (Musa } \\
\text { paradisiaca } L)\end{array}$ & hutan \\
\hline 9 & $\begin{array}{l}\text { - talas (Colocasia } \\
\text { sp) } \\
\text { - kamboja } \\
\quad(\text { Plumeria } s p)\end{array}$ & Permukiman \\
\hline
\end{tabular}

candi mempunyai relief baik berupa relief cerita maupun relief penghias dan pengisi bidang berupa sulursuluran. Dalam penelitian ini relief yang diambil adalah relief pada pipi tangga masuk candi dan beberapa relief pada tubuh candi. Hal ini karena relief tersebut memiliki penggambaran relief tanaman yang naturalis sehingga mampu memberikan keterangan mengenai suatu jenis tumbuhan.

Pada Candi Mendut pengambilan data dimulai dari pipi tangga sebelah selatan, kemudian dilanjutkan pada pipi tangga sebelah utara. Selanjutnya mengamati semua relief pada dinding candi. Bagian ini mempunyai relief pada sisi Utara dan Selatan, yakni dua panel relief Hariti dan Atavaka.

\section{Candi Borobudur}

Karmawibhangga merupakan relief cerita yang menghiasi bagian paling bawah candi (kamadhatu). Relief Karmawibhangga berisi ajaran hukum sebab akibat atau hukum karma yang dipahatkan dalam 160 panel relief. Menurut Kempers, penuangan naskah Karmawibhangga ke dalam panel relief pada Candi Borobudur sepertinya kurang lengkap, tidak seperti pada naskah aslinya, sebab hanya terdapat 23 panel saja yang dapat dikembalikan kepada naskah aslinya. Dengan demikian menurut Bernet Kempers naskah Karmawibhangga yang dituangkan pada kaki Candi Borobudur tersebut adalah naskah ringkas saja (Kempers dan Soekmono, 1974: 29-30).

Pada tingkatan selanjutnya yaitu rupadhatu, dijumpai relief cerita Lalitvistara, Jatakamala, Jataka/Avadana, Gandavyuha, dan Bhadracari. Seratus dua puluh panel relief Lalitavistara menceritakan mengenai kelahiran Sang Buddha (Pangeran Sidharta Gautama) hingga mencapai pencerahan. Cerita Lalitavistara digambarkan pada dinding lorong pertama yang diakhiri dengan penggambaran Budha yang menyampaikan ajarannya di Taman Rusa, Benares. Relief cerita selanjutnya adalah relief tentang ajaran-ajaran kehidupan berupa budi pekerti yang berlandaskan konsep Buddhisme yang diajarkan oleh para Dhyani Bodhisatwa. Relief tersebut adalah relief Jatakamala, Jataka/Avadana, Gandavyuha, dan 
Bhadracari yang merupakan cerita mengenai Dhyani Bodhisatwa Maitreya, Samantabadra, Sudhana dan Dhyani Bodhisatwa yang lain.

Data relief tanaman pada Candi Borobudur pada kajian ini diambil dengan metode purposif sampling. Relief tanaman yang diambil adalah dari relief yang mengandung aktivitas manusia dengan setting pada suatu ruang masyarakat masa lalu (permukiman, hutan, kolam, danau, lingkungan kerajaan, taman, desa, lahan budidaya, pasar, dll). Berdasarkan hal tersebut, dengan demikian maka relief yang akan digunakan sebagai data adalah relief yang mempunyai konteks penggambaran tanaman yang berada di sekitar aktivitas manusia masa lalu.

\section{Relief Karmawibhangga}

yang $\begin{array}{cr}\text { Pada tahun 1885, Ir. IJzerman } \\ \text { merupakan ketua }\end{array}$

Archaelogische Vereeniging secara tidak sengaja menemukan kembali

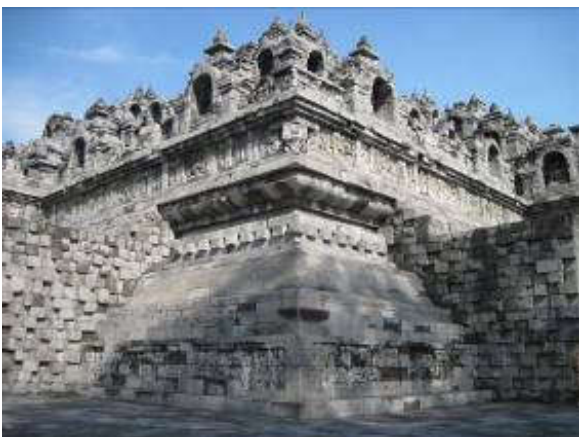

Gambar 6. Keletakan relief

karmawibhangga pada kaki candi yang tertutup struktur selasar dan undag

(Sumber: Balai Konservasi Borobudur, $200 \pi$

relief yang berada pada kaki candi yang telah tertutup oleh struktur batu selasar dan undag. Relief tersebut kemudian disebut dengan relief Karmawibhangga. Keletakan relief berada di sekeliling kaki candi dengan jumlah panel, 160. Setelah itu, kemudian pada tahun 1890, kaki candi yang berhias relief tersebut didokumentasikan dengan pemotretan pada tiap panelnya.

$\begin{array}{cr}\text { Relief } & \text { Karmawibhangga } \\ \text { dipahatkan berdasarkan kitab }\end{array}$

Tabel 3. Jenis tanaman dan konteks penggambarannya pada relief cerita Karmawibhangga Candi Borobudur.

\begin{tabular}{lll}
\hline No. & \multicolumn{1}{c}{ Jenis Tanaman } & \multicolumn{1}{c}{ Konteks Tanaman } \\
\hline 1 & Ketapang (Terminalia catappa $L)$ & Permukiman, hutan \\
\hline 2 & Keben (Baringtonia asiatica) & Permukiman, hutan \\
\hline 3 & Manggis (Garcinia mangostana) & permukimanwihara \\
\hline 4 & Teratai (Nymphaea sp) & danau \\
\hline 5 & Pisang (Musa paradisiaca) & Permukiman \\
\hline 6 & Nyamplung (Calophylum inophylum) & Permukiman, wihara \\
\hline 7 & Kamboja (Plumeria sp) & permukiman \\
\hline 8 & Keluwih (Arthocarpus comunis) & permukiman \\
\hline 9 & Jambu biji (Psidium guajava) & permukiman \\
\hline 10 & Mangga (Mangifera sp) & $\begin{array}{l}\text { Tempat } \\
\text { peribadatan, }\end{array}$ \\
& & permukiman \\
\hline 11 & Pinang sirih (Areca catechu L) & permukiman \\
\hline 12 & Pohon bodi (Ficus reliegiosus) & permukiman
\end{tabular}




\begin{tabular}{lll}
\hline 13 & Lontar (Borassus flabellifer) & permukiman \\
\hline 14 & Nangka (Artocarpus heterophyllus) & permukiman \\
\hline 10 & Biola cantik(Ficus pandurata) & permukiman \\
\hline 11 & Padi budidaya (Oryza sativa) & Sawah, permukiman \\
\hline 12 & Sukun (Arthocarpus integra) & permukiman \\
\hline 13 & Tanjung (Mimusops elengt) & permukiman \\
\hline 15 & Kelapa (Cocos nucifera $L)$ & permukiman \\
\hline 16 & Rumput gajah (Pennisetum purpurium) & hutan \\
\hline
\end{tabular}

Mahakarmawibhangga. Kitab ini berisi tentang hubungan sebab akibat didalam kehidupan manusia. Setiap panel pada relief Karmawibhangga selalu merupakan lukisan dari hal tersebut. Bagian panel sebelah kanan merupakan sebab dan bagian kirinya adalah akibatnya. Hal tersebut dapat diketahui secara pasti dikarenakan adanya inskripsi pendek berbahasa sanskerta yang merupakan panduan bagi pemahat untuk memahat relief pada bidang kaki candi (Faizaliskandar, 1987: 3).

$$
\text { Bernet Kempers (1976) }
$$

berpendapat bahwa relief Karmawibhangga adalah gambaran yang sebenarnya dari kehidupan sehari-hari masyarakat Jawa Kuna khususnya pada abad VIII-IX. Adegan pada panel relief tersebut menyimpan banyak informasi. Informasi tersebut di antaranya mengenai flora dan fauna, lingkungan alam, bentuk pakaian dan status sosial, alat musik, alat upacara, alat transportasi, arsitektur bangunan, peranan wanita, senjata, payung. Informasi tersebut mengarahkan kita pada teknologi dan kearifan budaya masyarakat Jawa Kuna terhadap lingkungan.

\section{Relief Lalitavistara}

Relief Lalitavistara Candi Borobudur dipahatkan pada dinding lorong I baris panel atas Candi Borobudur. Lalitavistara menceritakan kehidupan Siddharta Gautama/Sakyamuni. Dalam panel relief Lalitavistara diceritakan kehidupan Sakyamuni hingga mencapai pencerahan dan mengajarkan dharma di Benares.

$$
\text { Cerita dimulai ketika }
$$

Boddhisatwa masih berada di kayangan yang kemudian terlahir kembali melalui rahim Maya, seorang permisuri dari Raja Suddhodhana.

Tabel 4. Jenis tanaman dan konteks penggambarannya pada relief cerita Lalitavistara Candi Borobudur.

\begin{tabular}{lll}
\hline No. & \multicolumn{1}{c}{ Jenis Tanaman } & \multicolumn{1}{c}{ Konteks Tanaman } \\
\hline 1 & Bodhi (Ficus religiosa) & Hutan, Istana dewa, Istana \\
\hline 2 & keben (Baringtonia asiatica) & $\begin{array}{l}\text { Istana dewa, Permukiman, Istana, Hutan, } \\
\text { Tempat peribadatan, aman }\end{array}$ \\
\hline 3 & waru (Hibiscus tiliaceus) & Istana dewa, Istana, Pertapaan, Permukiman, \\
& & Hutan, sungai, aman
\end{tabular}


$4 \quad$ Mangga (Mangifera sp)

Istana, Hutan, Istana dewa, Asrama,

Pertapaan, Telaga, Sungai, Tempat

peribadatan

$5 \quad$ Nyamplung (Calophyllum iniophyllum) $\quad$ Istana, Hutan, Istana dewa, taman, Sungai

6 ketapang (Terminalia catappa L) Istana, Istana dewa, Permukiman, Hutan,

Pertapaan, Telaga, Sungai

\begin{tabular}{lll}
\hline 7 & jarak (Jatropha curcas) & Permukiman, Taman, Hutan \\
\hline 8 & pinang (Areca cathechu) & Istana \\
\hline 9 & Jambu (Psidium guajava) & Istana, Taman, hutan \\
\hline 10 & Kelapa (Cocos nucifera) & permukiman \\
\hline
\end{tabular}

11 Asam Jawa (Tamarindus indica) taman

\begin{tabular}{lll}
\hline 12 & Nagasari (Mesua ferrea) & Istana, hutan \\
\hline 13 & Lontar (Borassus flabellifer) & Istana, Taman
\end{tabular}

$14 \quad$ Durian (Durio zibethinus) Istana

15 Nangka (Arthocarpus heterophylus) Taman, Istana, Pertapaan, Hutan

16 Pisang (Musa paradisiaca) Hutan, Tempat peribadatan

17 sukun (Artocarpus integra) Hutan

18 kamboja (Plumeria sp) Hutan

19 teratai (Nymphaea sp) Telaga

20 rumput gajah (Pennisetum purpurium) Hutan, sungai, taman

Jenis Tanaman pada Prasasti dan Naskah Kesusastraan

Informasi mengenai tanaman yang terdapat pada masa Jawa Kuna di Kawasan Borobudur, selain diperoleh dari relief, juga diperoleh dari sumber tertulis berupa prasasti dan naskah kesusastraan. Data prasasti yang digunakan dalam penelitian ini adalah prasasti dari masa Mataram Kuna periode Jawa Tengah abad IX-X M, dengan asumsi bahwa Kawasan Borobudur adalah wilayah Kerajaan Mataram Kuna. Jenis tanaman yang teridentifikasi pada relief Karmawibhangga dan Lalitavistara dapat dibuktikan menggunakan data dukung parasasti Jawa Kuna abad IX$\mathrm{X}$ M, maupun naskah kesusastraan. Tanaman yang teridentifikasi dari prasasti ataupun naskah kesusastraan, juga dapat digunakan pada kajian ini untuk mengetahui jenis tanaman secara lebih lengkap apabila tanaman tersebut tidak digambarkan pada relief. Berikut ini adalah jenis tanaman yang dijumpai pada prasasti Jawa Kuna.

Tabel 5. Daftar jenis tanaman pada masa Jawa Kuna dari sumber prasasti Jawa Kuna abad IX-X M (Setyawan, 2007).

\begin{tabular}{llll}
\hline No & $\begin{array}{l}\text { Jenis Tanaman } \\
\text { Dalam Prasasti }\end{array}$ & \multicolumn{1}{c}{ Keterangan } & Nama Spesies \\
\hline 1 & asam pañjang & Asem Jawa. & Tamarindus indica $L$ \\
\hline 2 & bavang & $\bullet$ Bawang & $\bullet$ Allium cepa $L$ \\
& bawang & $\bullet$ Jenis mangga & $\bullet$ Mangifera foetida Loer \\
\hline
\end{tabular}




\begin{tabular}{|c|c|c|c|}
\hline 3 & $\begin{array}{l}\text { bras, garas, padi } \\
\text { prās, věas, vras }\end{array}$ & beras & $\begin{array}{l}\text { Oryza sativa L, Oryza sativa L forma } \\
\text { glutinosa, atau Oryza sativa L var. culta }\end{array}$ \\
\hline 4 & duvĕg & Duwet/ juwet. & Eugenia cumini Druse \\
\hline 5 & gagā & Padi gaga. & Oryza sativa L var. culta \\
\hline 6 & galagah & Tebu liar. & Saccharum spontaneum $L$ \\
\hline 7 & $\begin{array}{l}\text { gulma } \\
\text { suket }\end{array}$ & $\begin{array}{l}\text { Rumput pengganggu. } \\
\text { Jenis alang-alang. }\end{array}$ & $\begin{array}{l}\text { Imperata cylindrica Beauv. Var. major } \\
H u b b\end{array}$ \\
\hline 8 & jamvu & $\begin{array}{l}\text {-Jambu (air). } \\
\text { •Jambu (biji). }\end{array}$ & $\begin{array}{l}\text { - Eugenia aquea Burm. F } \\
\text { - Psidium guajava L }\end{array}$ \\
\hline 9 & jruk, limo & jeruk & Citrus sp \\
\hline 10 & kamalagi & Asem Jawa. & Tamarindus indica $L$ \\
\hline 11 & kambang & bunga & $?$ \\
\hline 12 & kapas & Kapas Jawa. & Gossypium purpurascens Poir \\
\hline 13 & kapas & kapas & Gossypium purpurascens Poir \\
\hline 14 & kasumba & kasumba & Bixa orellana $L$ \\
\hline 15 & kayu ara hivang & Kayu ara. & Ficiscilliase blume \\
\hline 16 & kауи hasam & Kayu asem Jawa. & Tamarindus indica $L$ \\
\hline 17 & kayu panda & Kayu panda. & $?$ \\
\hline 18 & Kubu-kubu & $\begin{array}{l}\text { Kabu-kabu/ kekabu/ } \\
\text { kapuk randu. }\end{array}$ & $\begin{array}{l}\text { Ceiba pentandra Gaertn, var. indica } \\
\text { Bakh }\end{array}$ \\
\hline 19 & limo manis & Jeruk manis. & Citrus sinensis $O s b$ \\
\hline 20 & limo susu & Jeruk nipis/ jeruk obat. & Citrus medica $L$ \\
\hline 21 & $\begin{array}{l}\text { limus galuh, } \\
\text { limus, poh, poh } \\
\text { dulur, poh galuh, } \\
\text { poh ronya }\end{array}$ & Daun mangga/ pakel. & Mangifera sp \\
\hline 22 & mayang & Pinang/ mayang. & Areca catechu $L$ \\
\hline 23 & nila & nila & Indigofera tinctoria $L$ \\
\hline 24 & padma & $\begin{array}{l}\text { Teratai yang mekar di } \\
\text { siang hari. }\end{array}$ & Nelumbo nucifera Gaertn \\
\hline 25 & phalaphali & Buah-buahan. & $?$ \\
\hline 26 & pipikan & jahe & Zingiber officinale Rosc \\
\hline 27 & pucang & Buah pinang & Areca catechu L \\
\hline 28 & pudak & Pandan & Pandanus tectorius Park \\
\hline
\end{tabular}




\begin{tabular}{|c|c|c|c|}
\hline 29 & $\begin{array}{l}\text { ron } \\
\text { ronya }\end{array}$ & $\begin{array}{l}\text { Daun, umumnya daun lontar } \\
\text { yang digunakan sebagai alas } \\
\text { untuk makan dalam upacara } \\
\text { penetapan sima } \\
\text { (sarkar,1972,hlm. 37). }\end{array}$ & Borassus flabellifer $L$ \\
\hline 30 & sîreh & sirih & Piper betle $L$ \\
\hline 31 & skar & bunga & $?$ \\
\hline 32 & skar campaga & Bunga cempaka. & Michelia champaca $L$ \\
\hline 33 & skar karaman & Bunga karaman. & $?$ \\
\hline 34 & skar tahun & Bunga tahun. & $?$ \\
\hline 35 & skar taju & Bunga taju. & $?$ \\
\hline 36 & skar tāl & Bunga lontar/ siwalan. & Borassus flabellifer $L$ \\
\hline 37 & $\begin{array}{l}\text { suradārumaȳ } \\
\text { (sanskerta) }\end{array}$ & Kayu dewadaru. & Mesua ferneal $L$ \\
\hline 38 & $\begin{array}{l}\text { sukun } \\
\text { sunkun }\end{array}$ & Sukun & Artocarpus atilis Park. Fsb \\
\hline 39 & tal & Lontar/ siwalan. & Borassus flabellifer $L$ \\
\hline 40 & talěs (patalěsan) & Talas/ keladi. & Colocasia esculentum Schott \\
\hline 41 & tañjung & teratai & Nymphaea sp \\
\hline 42 & $\begin{array}{l}\text { vali nāgapuspa, } \\
\text { navagrāha }\end{array}$ & Bunga nagasari/ dewadaru. & Mesua ferneal $L$ \\
\hline 43 & valu & Waluh/ labu. & Cucurbita moschata Duch \\
\hline 44 & $\begin{array}{l}\text { veņuvanā } \\
\text { (sanskerta) }\end{array}$ & Hutan bambu. & Bambusa sp \\
\hline 45 & $\begin{array}{l}\text { vras } \\
\text { caturvvarnna }\end{array}$ & $\begin{array}{l}\text { Beras empat warna (putih, } \\
\text { merah, hitam, kuning). }\end{array}$ & $\begin{array}{l}\text { Oryza sativa } L \text { dan Oryza sativa } \\
\text { forma glutinosa }\end{array}$ \\
\hline 46 & $\begin{array}{l}\text { vungkudu } \\
\text { wuñkudu } \\
\text { cungkudu }\end{array}$ & Mengkudu & Morinda citrofolia $L$ \\
\hline 47 & $\begin{array}{l}\text { vuru } \\
\text { vuru tlu } \\
\text { vuru tunggal }\end{array}$ & Pohon wuru. & Actinodaphne glomerata Nees \\
\hline 48 & & Teratai putih. & Nymphaea sp \\
\hline 49 & & Teratai biru. & Nymphaea sp \\
\hline
\end{tabular}


Tabel 6. Daftar jenis tanaman dan istilah yang mengindikasikan pengelolaan tanaman dari sumber naskah Ramayana Jawa Kuna (Setyawan,2007).

\begin{tabular}{|c|c|c|c|}
\hline No & $\begin{array}{l}\text { Jenis Tanaman/ } \\
\text { Indikasinya } \\
\text { (Jawa Kuna) }\end{array}$ & Keterangan & $\begin{array}{l}\text { Nama Spesies/ } \\
\text { Indikasi Flora }\end{array}$ \\
\hline 1 & açokâ & asoka & Jonesia asoka Roxb \\
\hline 2 & ańsana & angsana & $\begin{array}{l}\text { Pterocarpus indicus } \\
\text { Willd }\end{array}$ \\
\hline 3 & aměcěl-mécĕl & Pecel/ gado-gado. & $\begin{array}{l}\text { Bermacam-macam } \\
\text { sayuran. }\end{array}$ \\
\hline 4 & brěm & $\begin{array}{l}\text { Merupakan minuman beralkohol } \\
\text { yang dibuat dari, } \\
\text { - Beras, } \\
\text { - Beras ketan, } \\
\text { - Jagung, atau } \\
\text { - Gadung (Haryono,1994:hlm. } \\
\text { 13). }\end{array}$ & $\begin{array}{l}\text { - Oryza sativa L } \\
\text { - Oryza sativa forma } \\
\text { glutinosa. } \\
\text { - Zea mays L } \\
\text { - Dioscorea hipsida } \\
\text { Dennst }\end{array}$ \\
\hline 5 & câmpaka & cempaka & Michelia champaca $L$ \\
\hline 6 & candanâ & Pohon cendana. & Santalum album Linn \\
\hline 7 & çrigadin & Sri gading. & $\begin{array}{l}\text { Nyctanthes arbor-tritis } \\
L\end{array}$ \\
\hline 8 & dâlima & delima & Punica granatum $L$ \\
\hline 9 & daluwań wedihanya & $\begin{array}{l}\text { Kain daluwang dari merang atau } \\
\text { batang padi maupun dari serat } \\
\text { nanas. }\end{array}$ & $\begin{array}{l}\text { Oryza sativa } L \text { dan } \\
\text { Ananas comosus } \\
\text { Merr }\end{array}$ \\
\hline 10 & draksa & Anggur (grapes). & $\begin{array}{l}\text { Vitis vinifera } \\
\text { (Vitaceae) }\end{array}$ \\
\hline 11 & duhĕt & Duwet/ juwet. & $\begin{array}{l}\text { Eugenia cumini } \\
\text { Druse }\end{array}$ \\
\hline 12 & durian & durian & $\begin{array}{l}\text { Durio zibethinus } \\
\text { Murr }\end{array}$ \\
\hline 13 & duray & kasumba & Bixa orellana $L$ \\
\hline 14 & dwa-dwal & $\begin{array}{l}\text { Makanan yang diolah dari ketan } \\
\text { dengan dicampur gula aren juga } \\
\text { buah-buahan. }\end{array}$ & $\begin{array}{l}\text { Oryza sativa forma } \\
\text { glutinosa dan Arenga } \\
\text { pinnata Merr. }\end{array}$ \\
\hline 15 & gaga & $\begin{array}{l}\text { Ladang atau tegalan untuk } \\
\text { menanam padi gaga. }\end{array}$ & $\begin{array}{l}\text { Oryza sativa } L \text { var. } \\
\text { culta }\end{array}$ \\
\hline
\end{tabular}




\begin{tabular}{|c|c|c|c|}
\hline 16 & gadun & gadung & Dioscorea hipsida Dennst \\
\hline 17 & horgadin̈ & Bambu gading & Bambusa vulgaris Schrad \\
\hline \multirow[t]{2}{*}{18} & jambu & •Jambu (air). & - Eugenia aquea Burm. $F$ \\
\hline & & •Jambu (biji). & - Psidium gujava L \\
\hline 19 & jёnu & Boreh dengan campuran kunyit. & Curcuma longa $L$ \\
\hline 20 & kacapi & kecapi & Sandoricum koetjape Merr \\
\hline 21 & kanari & kenari & Canarium commune $L$ \\
\hline 22 & kapuṇụn & menteng & Baccauera racemosa M.A. \\
\hline 23 & Karkolakâ & cengkeh & Eugenia aromatika O.K. \\
\hline 24 & kaweni & Pohon kaweni. & Fam. Anacardiaceae \\
\hline 25 & kâwi putih. & Teratai/ tunjung/ seroja.(putih) & Nymphaea stellata wild \\
\hline 26 & kayu-teja & Kayu teja. & \\
\hline 27 & kinca & $\begin{array}{l}\text { Sirup dari buah kawista/ maja (van } \\
\text { Steenis,2005:hlm. 240). }\end{array}$ & Feronia limonia Swingle \\
\hline 28 & kulub-kuluban & Daun-daunan yang direbus. & Bermacam-macam sayuran. \\
\hline 29 & kumuda & Teratai/ tunjung/ seroja.(merah) & $\begin{array}{l}\text { Nymphaea nouchali Burm. } \\
F\end{array}$ \\
\hline 30 & kurawa & kurawa & $?$ \\
\hline 31 & lambayuń & $\begin{array}{l}\text { Lembayung atau daun kacang } \\
\text { panjang. }\end{array}$ & Vigna unguiculata L. Walp \\
\hline 32 & lańsěp & duku & $\begin{array}{l}\text { Lansium domesticum } \\
\text { Correa }\end{array}$ \\
\hline 33 & $\operatorname{limo}$ & jeruk & Citrus sp \\
\hline 34 & lumbu & Keladi/ talas. & Colocasia esculentum Schott \\
\hline 35 & limus & Mangga atau pakel. & Mangifera $s p$ \\
\hline 36 & luruk-luruk & Luruk-luruk. & $?$ \\
\hline 37 & maja & kawista & Feronia limonia Swingle \\
\hline 38 & mandarâ & Mandara/ dadap. & Erythrina indica Lamk \\
\hline 39 & madhuka & maduka & Maduca indica $L$ \\
\hline 40 & mamayań & Pinang/ mayang. & Areca catechu $L$ \\
\hline 41 & mańgis & manggis & Garcinia mangostana $L$ \\
\hline 42 & mâstawa & Ciu (singkong). & Manihot esculenta Crantz \\
\hline 43 & mĕņḍr & Melur/ melati. & Jasminum multiflorum Andr \\
\hline 44 & nâgapuşpa & Nagasari/ nagakesara/ dewadaru. & Mesua ferneal $L$ \\
\hline 45 & nańka & nangka & $\begin{array}{l}\text { Artocarpus heterophylla } \\
\text { Lamk }\end{array}$ \\
\hline
\end{tabular}




\begin{tabular}{|c|c|c|c|}
\hline 46 & nёp & nep & $?$ \\
\hline 47 & $n y \hat{u}$ & Nyiur/ kelapa. & Cocos nucifera $L$ \\
\hline 48 & nyû-gadinń & Kelapa gading. & Cocos nucifera, var. eburnea \\
\hline 49 & pacar & pacar & Impatiens platypetala Lindl \\
\hline 50 & paṇ̦akaki & $\begin{array}{l}\text { Pondokaki atau mondokaki } \\
\text { (Suryowinoto,1997:hlm. 50). }\end{array}$ & Ervatamia divarigata L. Burk \\
\hline 51 & pari & Padi & Oryza sativa $L$ \\
\hline 52 & pârịjâta & $\begin{array}{l}\text { Parijoto atau sering disebut sri gading } \\
\text { oleh masyarakat } \quad \text { Jawa } \\
\text { (Suryowinoto,1997:hlm. 166). }\end{array}$ & Nyctanthes arbor-tritis $L$ \\
\hline 53 & pathani & Persawahan atau perkebunan. & \\
\hline 54 & payańgu & pajanggu & $?$ \\
\hline 56 & phala mûla & Buah-buahan dan umbi-umbian. & $?$ \\
\hline 57 & pisań & pisang & Musa paradisiaca $L$ \\
\hline 58 & poh & Mangga atau pakel. & Mangifera sp \\
\hline 59 & pudak & pandan & Pandanus tectorius Park \\
\hline 60 & punnâga & Punaga/ benaga/ nyamplung. & Calophyllum inophyllum $L$ \\
\hline 61 & raṇ̣̂ö & Kapuk randu/ randu. & $\begin{array}{l}\text { Ceiba pentandra Gaertn, var. } \\
\text { indica Bakh }\end{array}$ \\
\hline 62 & sagula & gula & $?$ \\
\hline 63 & saruni & seruni & Wedelia sp \\
\hline 64 & sawah & $\begin{array}{l}\text { Persawahan atau lahan untuk } \\
\text { menanam padi dengan sistem irigasi. }\end{array}$ & Oryza sativa $L$ \\
\hline 65 & sěkul kĕpě-kĕpě & Nasi untuk sarapan. & Oryza sativa $L$ \\
\hline 66 & setu & pematang & \\
\hline 67 & sidhû & $\begin{array}{l}\text { Minuman keras yang dibuat dari tetes } \\
\text { tebu. }\end{array}$ & Saccharum officinarum $L$ \\
\hline 68 & sulasih & telasih & Ocimum basilicum $L$ \\
\hline 69 & tal & Lontar/ siwalan. & Borassus flabellifer $L$ \\
\hline 70 & tales & talas & Colocasia esculentum Schott \\
\hline 71 & tambul asiń & sirih & Piper betle $L$ \\
\hline 72 & těbû & tebu & Saccharum officinarum $L$ \\
\hline 73 & tĕgal-těgal & $\begin{array}{l}\text { Ladang/ tegalan untuk menanam padi } \\
\text { atau palawija. }\end{array}$ & $\begin{array}{l}\text { Padi (Oryza sativa L) dan } \\
\text { jenis palawija }\end{array}$ \\
\hline 74 & thani & petani & $?$ \\
\hline
\end{tabular}




\begin{tabular}{|c|c|c|c|}
\hline 75 & tunjjuń abâń & Teratai/ tunjung/ seroja.(merah) & Nelumbo nucifera Gaertn \\
\hline 76 & wariń in & beringin & Ficus benyamina $L$ \\
\hline 77 & wuńawari & worawari & Hibiscus rosa-sinensis $L$ \\
\hline 78 & wuń lawn & rambutan & Nephelium lappaceum $L$ \\
\hline 79 & $\begin{array}{l}\text { “..pada Santosa } \\
\text { ri kań kulit } \\
\text { kayu...” }\end{array}$ & $\begin{array}{l}\text { Bersama-sama memakai pakaian kulit } \\
\text { kayu. (waru atau rosella). }\end{array}$ & $\begin{array}{l}\text { Hibiscus tiliaceus } L \text { atau } \\
\text { Hibiscus sabdariffa } L\end{array}$ \\
\hline 80 & $\begin{array}{l}\text { “...seroja } \\
\text { rińtalaga... } \\
\text { mabâń } \\
\text { maputih..." }\end{array}$ & $\begin{array}{l}\text { Bunga seroja di telaga yang berwarna } \\
\text { merah dan putih. }\end{array}$ & $\begin{array}{l}\text { Nymphaea stellata wild dan } \\
\text { Nelumbo nucifera Gaertn }\end{array}$ \\
\hline
\end{tabular}

Berdasarkan sumber prasasti dan naskah Ramayana Jawa Kuna beberapa jenis tanaman yang dikenal dan dibudidayakan pada masa Jawa Kuna. Mengenai jenis tanaman yang disebut terdapat persamaan dan perbedaan. Tanaman yang disebut dalam prasasti agaknya merupakan tanaman yang dijumpai pada masa itu. Jenis tanaman yang disebut dalam naskah perlu mendapat perhatian tersendiri, karena ada beberapa tanaman yang tidak atau sulit tumbuh di Jawa, seperti cendana (Santalum album Linn). Sementara itu, naskah Ramayana Jawa Kuna juga menyebut tanaman dengan bahasa yang asing, yaitu luruk-luruk, kurawa, atau panyagu.

Keterangan mengenai pengelolaan sumber daya flora berdasarkan sumber prasasti dan naskah kesusastraan relatif sama.
Berbagai jenis lahan yang disebut dalam prasasti, di antaranya sawah, tegalan atau ladang, maupun kebun juga disebut dalam naskah kesusastraan.

Beberapa jenis pohon maupun tanaman, seperti nep, kurawa, lurukluruk, dan payangu adalah jenis pohon yang tidak dikenal dalam istilah Jawa. Tanaman tersebut kemungkinan hanya tumbuh di India atau terdapat di Jawa, tetapi dikenal dengan nama lain, yang hingga kini belum teridentifikasi.

\section{KLASIFIKASI DAN ANALISIS KONTEKSTUAL}

\section{Klasifikasi Tanaman Sesuai Konteks Penggambarannya}

Tabel 7. Jenis tanaman dan konteks penggambarannya pada relief cerita Candi Mendut

\begin{tabular}{llll}
\hline No. & Konteks Tanaman & \multicolumn{1}{c}{ Panel Relief } & \multicolumn{1}{c}{ Jenis Tanaman } \\
\hline 1 & Permukiman & M1, M4, M5, M9 & $\bullet$ mangga (mangifera sp) \\
& & & $\bullet$ talas (Colocasia sp) \\
& & $\bullet$ kamboja (Plumeria sp) \\
\hline 2 & Pertapaan & M3, M7 & $\bullet$ Jambu dersana (Eugenia malaccensis \\
& & $L$ L)
\end{tabular}




\begin{tabular}{|c|c|c|c|}
\hline 3 & Hutan & M2, M6, M8 & $\begin{array}{l}\text { - Mangga (mangifera sp) } \\
\text { - ketapang (Terminalia catappa L) } \\
\text { - pisang (Musa paradisiaca L) }\end{array}$ \\
\hline
\end{tabular}

Tabel 8. Jenis tanaman dan konteks penggambarannya pada relief cerita Karmawibhangga Candi Borobudur.

\begin{tabular}{|c|c|c|c|}
\hline No. & Konteks Tanaman & Panel Relief & Jenis Tanaman \\
\hline 1 & Permukiman & $\begin{array}{l}\text { BK } 6, \text { BK 9, BK 13, BK } \\
20, \text { BK } 21, \text { BK } 24, \text { BK } \\
34, \text { BK } 39, \text { BK } 42, \text { BK } \\
50, \text { BK } 55, \text { BK } 59, \text { BK } \\
60, \text { BK } 61, \text { BK } 65, \text { BK } \\
74, \text { BK } 75, \text { BK } 76, \text { BK } \\
79, \text { BK } 97, \text { BK } 107, \text { K } \\
117, \mathrm{BK} 122\end{array}$ & $\begin{array}{l}\text { - Biola cantik (Ficus pandurata) } \\
\text { - jambu biji (Psidium guajava) } \\
\text { - kamboja (Plumeria sp) } \\
\text { - keben (Baringtonia asiatica) } \\
\text { - keben (Baringtonia asiatica) } \\
\text { - kelapa (Cocos nucifera L) } \\
\text { - keluwih (Arthocarpus comunis) } \\
\text { - ketapang (Terminalia catappa L) } \\
\text { - lontar (Borassus flabellifer) } \\
\text { - mangga (mangifera sp) } \\
\text { - manggis (Garcinia mangostana) } \\
\text { - nangka (Artocarpus heterophyllus) } \\
\text { - nyamplung (Calophylum inophylum) } \\
\text { - pohon bodi (Ficus reliegiosus) } \\
\text { - rumput gajah (Pennisetum purpurium) } \\
\text { - sukun (Arthocarpus integra) } \\
\text { - tanjung (Mimusops elengt) } \\
\text { - teratai (Nymphaea sp) }\end{array}$ \\
\hline 2 & $\begin{array}{l}\text { Permukiman } \\
\text { (danau) }\end{array}$ & BK 9 & $\begin{array}{l}\text { - manggis (Garcinia mangostana) } \\
\text { - teratai (Nymphaea sp) }\end{array}$ \\
\hline 3 & $\begin{array}{l}\text { Tempat } \\
\text { Peribadatan }\end{array}$ & BK 24, BK 124 & $\begin{array}{l}\text { - ketapang (Terminalia catappa L) } \\
\text { - mangga (Mangifera sp) } \\
\text { - manggis (Garcinia mangostana) }\end{array}$ \\
\hline 4 & $\begin{array}{l}\text { Permukiman } \\
\text { (wihara) }\end{array}$ & BK 42, BK 79 & • nyamplung (Calophylum inophylum) \\
\hline 5 & $\begin{array}{l}\text { Permukiman } \\
\text { (sawah) }\end{array}$ & BK 65 & - Padi budidaya (Oryza sativa) \\
\hline 6 & Hutan & $\begin{array}{l}\text { BK 87, BK 93, BK 105, } \\
\text { BK 118, }\end{array}$ & $\begin{array}{l}\text { - keben (Baringtonia asiatica) } \\
\text { - ketapang (Terminalia catappa L) } \\
\text { - mangga (Mangifera sp) } \\
\text { - pisang (Musa paradisiaca) } \\
\text { - rumput gajah (Pennisetum purpurium) } \\
\text { - sukun (Arthocarpus integra) }\end{array}$ \\
\hline
\end{tabular}




\begin{tabular}{|c|c|c|c|}
\hline 7 & $\begin{array}{l}\text { Permukiman } \\
\text { (tegalan) }\end{array}$ & BK 122, BK 123 & $\begin{array}{l}\text { - ketapang (Terminalia catappa L) } \\
\text { - mangga (Terminalia catappa L) } \\
\text { - padi (Oryza sativa) } \\
\text { - pisang (Musa paradisiaca) }\end{array}$ \\
\hline
\end{tabular}

Tabel 9. Jenis tanaman dan konteks penggambarannya pada relief cerita Lalitavistara Candi Borobudur

\begin{tabular}{|c|c|c|c|}
\hline No. & Konteks Tanaman & Panil Relief & Jenis Tanaman \\
\hline 1 & Hutan & $\begin{array}{l}\text { BL } 4, \text { BL } 67, \text { BL } 69, \text { BL } \\
74, \text { BL } 75, \text { BL } 76, \text { BL } \\
78, \text { BL } 79, \text { BL } 80, \text { BL } \\
83, \text { BL } 88, \text { BL } 95, \text { BL } \\
\text { 100, BL 102, BL 103, } \\
\text { BL 106, BL 108, BL } 110\end{array}$ & $\begin{array}{l}\text { - Bodhi (Ficus religiosa) } \\
\text { - jambu (Psidium guajava) } \\
\text { - Jarak (Jatropa curcas) } \\
\text { - kamboja (Plumeria sp) } \\
\text { - keben (Baringtonia asiatica) } \\
\text { - ketapang (Terminalia catapa) } \\
\text { - Mangga (Mangifera sp) } \\
\text { - Nagasari (Mesua ferrea) } \\
\text { - Nangka (Arthocarpus heterophylus) } \\
\text { - Nyamplung (Calophyllum } \\
\text { iniophyllum) } \\
\text { - Pisang (Musa paradisiaca) } \\
\text { - rumput gajah (Pennisetum purpurium) } \\
\text { - sukun (Artocarpus integra) } \\
\text { - Waru (Hibiscus tiliaceus) }\end{array}$ \\
\hline 2 & Istana Dewa & BL 5, BL 7, & $\begin{array}{l}\text { - Bodhi (Ficus religiosa) } \\
\text { - keben (Baringtonia asiatica) } \\
\text { - ketapang (Terminalia catappa L) } \\
\text { - waru (Hibiscus tiliaceus) }\end{array}$ \\
\hline 3 & Istana & $\begin{array}{l}\text { BL } 8, \text { BL } 9, \text { BL } 13, \text { BL } \\
19, \text { BL } 21, \text { BL } 22, \text { BL } \\
24, \text { BL } 29, \text { BL } 30, \text { BL } \\
36, \text { BL } 41, \text { BL } 51, \text { BL } \\
53, \text { BL } 65\end{array}$ & $\begin{array}{l}\text { - Bodhi (Ficus religiosa) } \\
\text { - Durian (Durio zibethinus) } \\
\text { - Jambu (Psidium guajava) } \\
\text { - keben (Baringtonia asiatica) } \\
\text { - ketapang (Terminalia catappa L) } \\
\text { - Lontar (Borassus flabellifer) } \\
\text { - Mangga (Mangifera sp) } \\
\text { - Nagasari (Mesua ferrea) } \\
\text { - Nangka (Arthocarpus heterophylus) } \\
\text { - Nyamplung (Calophyllum } \\
\text { imiophyllum) pinang (Areca cathechu) } \\
\text { - waru (Hibiscus tiliaceus) }\end{array}$ \\
\hline
\end{tabular}




\begin{tabular}{|c|c|c|c|}
\hline 4 & Permukiman & $\begin{array}{l}\text { BL 18, BL 23, BL 58, } \\
\text { BL } 81\end{array}$ & $\begin{array}{l}\text { - jarak (Jatropha curcas) } \\
\text { - keben (Baringtonia asiatica) } \\
\text { - Kelapa (Cocos nucifera) } \\
\text { - Ketapang (Terminalia catappa L) } \\
\text { - waru (hibiscus tiliaceus) }\end{array}$ \\
\hline 5 & Taman & $\begin{array}{l}\text { BL } 27, \text { BL 40, BL 49, } \\
\text { BL } 117\end{array}$ & $\begin{array}{l}\text { - Asam Jawa (Tamarindus indica) } \\
\text { - Jambu (psidium guajava) } \\
\text { - Jarak (Jatropha curcas) } \\
\text { - keben (Baringtonia asiatica) } \\
\text { - Lontar (Borassus flabellifer) } \\
\text { - Nangka (Arthocarpus heterophylus) } \\
\text { - Nyamplung (Calophyllum iniophyllum) } \\
\text { - rumput gajah (Pennisetum purpurium) } \\
\text { - Waru (Hibiscus tiliaceus) }\end{array}$ \\
\hline 6 & Asrama & BL 38 & - Mangga (mangifera sp) \\
\hline 7 & Telaga & BL 82 & $\begin{array}{l}\text { - Mangga (Mangifera sp) } \\
\text { - ketapang (Terminalia catapa) } \\
\text { - teratai (Nymphaea sp) }\end{array}$ \\
\hline 8 & Pertapaan & BL 70, BL 71, BL 72 & $\begin{array}{l}\text { - Nangka (Arthocarpus heterophylus) } \\
\text { - Ketapang (Terminalia catapa) } \\
\text { - Mangga (Mangifera sp) } \\
\text { - Waru (Hibiscus tiliaceus) } \\
\text { - Mangga (Mangifera sp) }\end{array}$ \\
\hline 9 & Sungai & BL 85, BL 115 & $\begin{array}{l}\text { - ketapang (Terminalia catapa) } \\
\text { - Mangga (Mangifera sp) } \\
\text { - Nyamplung (Calophyllum iniophyllum) } \\
\text { - rumput gajah (Pennisetum purpurium) } \\
\text { - Waru (Hibiscus tiliaceus) }\end{array}$ \\
\hline 10 & $\begin{array}{l}\text { Tempat } \\
\text { peribadatan }\end{array}$ & BL 109 & $\begin{array}{l}\text { - keben (Baringtonia asiatica) } \\
\text { - mangga (Mangifera sp) } \\
\text { - pisang (Musa paradisiaca) }\end{array}$ \\
\hline
\end{tabular}

Konsep Penataan Tanaman Pada Zona I Candi Borobudur dan Candi Mendut

Konsep penataan tanaman yang dimaksudkan adalah rencana penanaman tamanan seperti yang telah teridentifikasi dari relief, prasasti, maupun naskah kesusastraan. Rencana penanaman tersebut harus disesusaikan dengan beberapa kriteria di bawah ini. Hal ini karena Candi Borobudur adalah merupakan warisan budaya dunia dengan atribut fisik berupa struktur candi dan lanskap budaya. Hal ini berarti tanaman yang akan ditanam tidak boleh membahayakan struktur Candi Borobudur. Berikut ini adalah kriteria tanaman yang akan dapat di 
tanam pada zona pelestarian pada Candi Borobudur dan Candi Mendut.

1. Kriteria tanaman pada Zona I Candi Borobudur dan Candi Mendut :

a) Memiliki nilai sejarah dan estetika;

b) tidak beracun, tidak berduri, dahan tidak mudah patah, perakaran tidak mengganggu pondasi;

c) tajuk cukup rindang dan kompak, tetapi tidak terlalu gelap;

d) ketinggian tanaman bervariasi, warna hijau dengan variasi warna lain seimbang;

e) perawakan dan bentuk tajuk cukup indah;

f) kecepatan tumbuh sedang;

g) berupa habitat tanaman lokal dan tanaman budidaya;

h) jenis tanaman tahunan atau musiman;

i) jarak tanam setengah rapat sehingga menghasilkan keteduhan yang optimal;

j) tahan terhadap hama penyakit tanaman;

k) mampu menjerap dan menyerap cemaran udara;

l) sedapat mungkin merupakan tanaman yang tidak mengundang burung atau serangga.

2. Kriteria tanaman untuk Taman Candi

a) memiliki ketinggian yang bervariasi;

b) sedapat mungkin merupakan tanaman yang mengundang kehadiran burung;

c) tajuk cukup rindang dan kompak; d) mampu menjerap dan menyerap cemaran udara;

e) tahan terhadap hama penyakit;

f) berumur panjang;

g) toleran terhadap keterbatasan sinar matahari dan air;

h) tahan terhadap pencemaran kendaraan bermotor dan industri;

i) batang dan sistem percabangan kuat;

j) batang tegak kuat, tidak mudah patah;

k) sistem perakaran yang kuat sehingga mampu mencegah terjadinya longsor;

l) seresah yang dihasilkan cukup banyak dan tidak bersifat alelopati, agar tumbuhan lain dapat tumbuh baik sebagai penutup tanah;

m)jenis tanaman yang ditanam termasuk golongan evergreen bukan dari golongan tanaman yang menggugurkan daun (decidous);

n) memiliki perakaran yang dalam.

3. Kriteria tanaman untuk jalur hijau dan pejalan kaki

Aspek silvikultur

a) berasal dari biji terseleksi sehat dan bebas penyakit;

b) memiliki pertumbuhan sempurna baik batang maupun akar;

c) perbandingan bagian pucuk dan akar seimbang;

d) batang tegak dan keras pada bagian pangkal;

e) tajuk simetris dan padat;

f) sistim perakaran padat.

Sifat biologi

a) tumbuh baik pada tanah padat; 
b) sistem perakaran masuk kedalam tanah, tidak merusak konstruksi dan bangunan;

c) fase anakan tumbuh cepat, tetapi tumbuh lambat pada fase dewasa;

d) ukuran dewasa sesuai ruang yang tersedia;

e) batang dan sistem percabangan kuat;

f) batang tegak kuat, tidak mudah patah dan tidak berbanir;

g) perawakan dan bentuk tajuk cukup indah;

h) tajuk cukup rindang dan kompak, tetapi tidak terlalu gelap;

i) ukuran dan bentuk tajuk seimbang dengan tinggi pohon;

j) daun sebaiknya berukuran sempit (nanofill);

k) tidak menggugurkan daun;

l) daun tidak mudah rontok karena terpaan angin kencang;

m)saat berbunga/berbuah tidak mengotori jalan;

n) buah berukuran kecil dan tidak bisa dimakan oleh manusia secara langsung;

o) sebaiknya tidak berduri atau beracun;

p) mudah sembuh bila mengalami luka akibat benturan dan akibat lain;

q) tahan terhadap hama penyakit;

r) tahan terhadap pencemaran kendaraan bermotor dan industri;

s) mampu menjerap dan menyerap cemaran udara;

t) sedapat mungkin mempunyai nilai ekonomi;

u) berumur panjang.

4. Kriteria tanaman untuk zona pengembangan
Peneduh

a) ditempatkan pada jalur tanaman (minimal 1,5 $\mathrm{m}$ dari tepi median);

b) percabangan $2 \mathrm{~m}$ di atas tanah;

c) bentuk percabangan batang tidak merunduk;

d) bermassa daun padat;

e) berasal dari perbanyakan biji;

f) ditanam secara berbaris;

g) tidak mudah tumbang.

Penyerap polusi udara

a) terdiri dari pohon, perdu/semak;

b) memiliki kegunaan untuk menyerap udara;

c) jarak tanam rapat;

d) bermassa daun padat.

Peredam kebisingan

a) terdiri dari pohon, perdu/semak;

b) membentuk massa;

c) bermassa daun rapat;

d) berbagai bentuk tajuk.

\section{KESIMPULAN}

Pada Kajian Penataan

Tanaman Kawasan Borobudur telah teridentifikasi jenis tanaman pada relief Candi Borobudur dan Candi Mendut. Seperti halnya telah disampaikan di awal, relief yang digunakan sebagai data adalah relief penggambaran tanaman yang bersifat naturalis.

Penggambaran relief tanaman pada Candi Mendut telah dilakukan pada kesemua panel relief cerita bertema Jataka/Avadana pada pipi tangga dan dinding candi. Beberapa relief tanaman yang diindetifikasi pada Candi Mendut di antaranya, mangga, jambu dersana, ketapang, 
pisang, talas, dan kamboja. Sedangkan konteks penggambaran tanaman yang teridentifikasi adalah pada permukiman, pertapaan, dan hutan.

Pengambilan data penggambaran relief tanaman pada Candi Borobudur dilakukan dengan cara purposive sampling. Hal ini karena selain banyaknya jumlah panel relief cerita pada Candi Borobudur, juga berulang-ulangnya penggambaran tanaman dengan konteksnya. Terkait dengan purposive sampling tersebut maka relief yang digunakan sebagai data adalah relief cerita Karmawibhangga dan Lalitavistara. Relief Karmawibhangga dinilai dapat merepresentasikan kondisi masyarakat pedesaan, sedangkan relief Lalivistara dapat menggambarkan lingkungan hisup seorang manusia sejak dilahirkan hingga dewasa dengan setting lokasi yang berbeda-beda.

Relief penggambaran tanaman yang dapat teridentifikasi pada Candi Borobudur khususnya pada relief Karmawibhangga adalah ketapang, keben, manggis, teratai, pisang, nyamplung, kamboja, keluwih, jambu biji, pinang, bodhi, nangka, lontar, padi, sukun, biola cantik, tanjung, rumput gajah, kelapa, dan jambu air. Adapun konteks penggambaran yang teridentifikasi adalah pada permukiman, danau, sawah, hutan, wihara, dan tempat peribadatan.

Selain itu, penggambaran tanaman yang dapat dijumpai khususnya pada relief Lalitavistara adalah bodhi, nyamplung, ketapang, keben, waru, mangga, jarak, pinang, kelapa, asam jawa, lontar, durian, nangka, jambu, pisang, keben, nagasari, sukun, kamboja, dan rumput gajah. Adapun untuk konteks penggambaran relief tanaman yang dijumpai adalah pada hutan, istana, permukiman, asrama, taman, pertapaan, telaga, sungai, dan tempat peribadatan.

Setelah melakukan identifikasi dengan metode purposive sampling, maka melalui sumber prasasti dan naskah kesusastraan Jawa Kuna maka eksistensi tanaman yang digambarkan pada relief tersebut dapat dipastikan. Hal ini karena pada beberapa prasasti dijumpai istilah-istilah Jawa Kuna yang berkaitan dengan tanaman ataupun pembudidayaan tanaman. Berdasarkan identifikasi tanaman dari relief dengan alat interpretasi prasasti dan naskah kesusastraan Jawa Kuna maka dapat disampaikan bahwa relief pada Candi Borobudur dan Candi Mendut merupakan gambaran kehidupan manusia pada masa lalu. Hal ini juga dapat dibuktikan dari jenis tanaman yang digambarkan pada relief candi, kesemuanya masih dijumpai di lingkungan Kawasan Borobudur hingga saat ini.

Berkaitan dengan konsep penataan tanaman pada zona pelestarian Candi Borobudur maupun Candi Mendut, hal tersebut masih memerlukan kajian lebih lanjut terkait analisa. Analisa yang akan dilakukan adalah dengan menyelaraskan jenis tanaman pada relief dengan kriteria tanaman yang telah disampaikan. Kriteria yang disusun merupakan elaborasi dari Pedoman Penyediaan dan Pemanfaatan Ruang Terbuka Hijau. Akan tetapi untuk menetapkan tanaman yang akan di tanam sesuai dengan kriteria di atas diperlukan analisa lebih lanjut terkait jenis ataupun famili dari tanaman yang teridentifikasi dari relief Candi Borobudur dan Candi Mendut. 


\section{DAFTAR PUSTAKA}

Atmadi, Parmono. (1979). Beberapa Patokan Perancangan Bangunan Candi. Disertasi. Dalam Pelita Borobudur, Seri C, No. 2. Magelang.

Balai Konservasi Peninggalan Borobudur. (1991). Data Ukuran Candi Borobudur.

Magelang: Balai Konservasi Peninggalan Borobudur.

Brink, van de. (1931). Welke Planten Vindt Men Op De Boroboedoer Afgebeeld De Tropische Natuur.

Cammerloher. (1931). Wat De Boroboedoer Den Natuurronderzoeker Leert dalam De Tropische Natuur.

Casparis, J.G. de. (1950). Prasasti Indonesia I. Bandung: A.C. Nix \& Co.

Darmosoetopo, Riboet. (2003). Sima dan Bangunan Keagamaan Di Jawa Abad IXX M. Jogjakarta: Prana Pena.

Jones, Antoinette M. Barrett. (1984). Early Tenth Century Java from The Inscription (A Study of Economic, Social, And Administrative Conditions in The First Quarter of The Century). U. S. A: Dordrecht-Holland/ Cinnaminson.

Kandahjaya, Hudaya. (1995). The Master Key for Reading Borobudur Simbolism. Bandung: Karaniya.

Kartodirdjo, Sartono dan Suryo, Djoko. (1991). Sejarah Perkebunan Di Indonesia: Kajian Sosial Ekonomi. Yogyakarta: Aditya Media.

Kempers, A.J. Bernet dan Soekmono. (1974). Candi Mendut, Pawon, dan Borobudur. Bandung-Jakarta: Ganaco NV.

Krom, N.J. (1927). Barabudur: Archaeological Description Vol I. The Hague: Martinus Nijhoff

Kusen (1984-1985). Kreativitas dan Kemandirian Seniman Jawa Dalam Mengolah Pengaruh Budaya Asing (Studi Kasus Tentang Gaya Seni Relief Candi di Jawa Abad IX-XVI). Yogyakarta: Depdikbud.

Miksik, John. (1990). Borobudur: Golden Tales of the Buddhas. Berkeley Singapore: Periplus.

Munandar, Agus Aris. (1995). Arsitektur Candi-candi di Jawa Timur: Sebuah Pembahasan Ringkas. Dalam Kirana: Persembahan untuk Prof. Dr. Haryati Soebadio. Jakarta: Fakultas Sastra Universitas Indonesia \& Intermasa.

Mundardjito. (2002). Pertimbangan Ekologis Penempatan Situs Masa HindhuBuddha Di Daerah Yogyakarta. Jakarta: Wedatama Widya Sastra dan Ecole Francaise d'Extreme-Orient.

Pusat Penelitian dan Pengembangan Arkeologi Nasional. (2008). Metode Penelitian Arkeologi. Jakarta: Puslibang Arkenas.

Sarkar, Himansu Bhusan. (1971). Corpus of The Inscription of Java (Corpus Inscriptionum Javanicarum) Vol. I. Calcuta: Firma K. L. Mukhopadhyay. 
Setyawan, Hari. 2007. Potensi dan Pengelolaan Sumberdaya Flora Kawasan Prambanan (Studi Kasus Relief Cerita Candi Prambanan dan Sojiwan) (Skripsi). Yogyakarta: Fakultas Ilmu Budaya UGM.

Soekmono. (1974). Candi, Fungsi, dan Pengertiannya (Disertasi). Jakarta: Universitas Indonesia

Steenis, C. G. G. J. van. (2005). Flora, Cetakan Kesepuluh. Jakarta: PT. Pradnya Paramita.

Steinmann, A. (1934). De op de Boroboedoer Afgebeelde Plantenwereld. Dalam Tijdsschrift Voor Indische Taal-Land- En Volkenkunde. Koninklijk Bataviaasch Genootschap Van Kunsten. 